\title{
Effect of Mulching on Growth and Yield of Soybean (Glycine max (L.) Merrill)
}

\author{
D. Daniel Anand*, M. Sumarjit Singh, Jamkhogin Lhungdim, \\ N. Surbala Devi and N. Gopimohan Singh
}

\author{
College of Agriculture, Central Agricultural University, Imphal, India
}

*Corresponding author

\section{A B S T R A C T}

\begin{tabular}{l} 
Ke y w o r d s \\
$\begin{array}{l}\text { Mulch, Rice straw, } \\
\text { Rice husk and } \\
\text { Polythene }\end{array}$ \\
Article Info \\
$\begin{array}{l}\text { Accepted: } \\
\text { 24 August } 2020 \\
\text { Available Online: } \\
\text { 10 September 2020 }\end{array}$ \\
\hline
\end{tabular}

To protect the environment, expand the earth's natural resource base and for maintaining the soil fertility sustainable agriculture plays an important role where, mulching is one of the major factor for sustainable agriculture technology. So, to study the best mulching practice in soybean and their feasibility a field experiment was carried out during the kharif season of 2019 at experimental field of College of Agriculture, Central Agricultural University, Imphal. The experiment comprised of seven different treatments (mulches) which are laid out in a randomized block design with three replications. These mulching practices significantly influenced the growth and yield of soybean where, higher values of plant height $(96.77 \mathrm{~cm})$, number of branches per plant (23.60), dry matter accumulation per plant $(44.01 \mathrm{~g})$, number of pods per plant $(84.2)$, test weight $(11.9 \mathrm{~g})$, grain yield $(2554.7 \mathrm{~kg} / \mathrm{ha})$, straw yield $(3260.7 \mathrm{~kg} / \mathrm{ha})$, biological yield $(5798.7 \mathrm{~kg} / \mathrm{ha})$ and harvest index $(44.1 \%)$ were observed in polythene mulching followed by mulching with rice straw @ $5 \mathrm{t} \mathrm{ha}^{-1}$. While control recorded the lowest in all aspects.

\section{Introduction}

Soybean (Glycine max (L.) Merill) belong to the order Fabales, family Fabaceae (Leguminosae), and subfamily Faboidede (Papilionoideae). It is an important crop worldwide, because it has a wide range of geographical adoption, unique chemical composition, good nutritional value, high yield potential, functional health benefits and variety of end users (food, feed and nonedible). Soybean has capacity to give return even under minimum agricultural inputs and management practices. It is extremely climate resilient and performs even under severe water stress and wet conditions. It fits well in cropping systems/rotations including inter-/mixed-cropping systems.

Moreover, as and legume, the crop improves soil fertility by fixing atmospheric nitrogen to the extent of $65-115 \mathrm{~kg} / \mathrm{ha}$ (Alexander, 1977) through phenomenon of symbiosis in root nodules depending upon agro climatic conditions, variety, strain etc. therefore soybean crop known as "Golden bean", "Miracle crop", "Wonder crop", and "gold of soil". 
Mulching is a desirable management practice which regulates farm environment and thereby enhances crop production through regulating soil temperature (Khan, 2001), by reducing leaching and evapotranspiration (Liu et al., 2000), by increasing the soil organic matter content (Roldan et al., 2003) and by reducing nutrient loss due to run off (Smart and Bradford, 1999). Organic mulches like paddy straw and rice husk are easily available in nature at affordable prices and are easily degradable in nature after their use. A rice crop yields a large amount of straw yield, which from the standpoint of health and environmental pollution, is one of the most critical problems in rice producing countries (FAO, 1982). A major portion of it is combusted on fields causing a great hazard to public health and the environment. Therefore, considerable attention has been placed on using straw in composting and feeding animals as it is cheap and abundant (Abdelhamid et al., 2004). However, Mendoza (1989) demonstrated that recycling rice straw could substitute 2-4 bags of fertilizers per hectare per cropping. Moreover, new approaches of using rice straw for controlling weeds in different crops have been suggested by Mendoza and Samson (1999) who indicated that rice straw can be used for mulching, which prevents weed growth and supplies organic matter for heterotrophic $\mathrm{N}$ fixing microorganisms, which could be utilized by succeeding crops (Patnaik, 1978).

The use of reflective mulch can improve photosynthetically active radiation/PAR (Sandler et al., 2009). The incoming solar radiation on the leaves will affect the distribution of chlorophyll. The presence of radiation that reaches the bottom of the leaf causes chlorophyll translocation so the absorption of light for photosynthesis becomes higher (June, 2002). Best weed control and lowest weed biomass were achieved by mulching with paper followed by
Polythene and biodegradable plastic (Anzalone et al., 2010).

\section{Materials and Methods}

The experiment was conducted during the kharif season of 2019 at experimental field of College of Agriculture, Central Agricultural University, Imphal, Manipur. The experimental site was located at $24^{0} 46^{\prime} \mathrm{N}$ latitude and $93^{\circ} 54^{\prime} \mathrm{E}$ longitude at an altitude of $775 \mathrm{~m}$ above the mean sea level. It comes under the Eastern Himalayan Region (II) and subtropical zone (NEH -4) of Manipur. The climatic condition of Imphal valley is subtropical. The rainy season usually begins by May and extends up to September. The average annual rainfall of Imphal valley is $1212 \mathrm{~mm}$ and the winter normally begins from mid November and extends up to the end of February. The amount of rainfall received during the crop period was $738 \mathrm{~mm}$. The soil of the experimental site was clay in texture with medium fertility status and acidic in reaction with a soil $\mathrm{pH}$ of 5.7. The chemical composition of the soil indicated that the soil was low in available nitrogen $(210.11 \mathrm{~kg} / \mathrm{ha})$, medium in available phosphorus (22.89 kg/ha), medium in available potassium $(239.83 \mathrm{~kg} / \mathrm{ha})$ and high in organic carbon content $(1.35 \%)$.

The experiment was laid out in a Randomized Block Design with seven treatments replicated thrice. The treatments were T1: Rice straw@5 t ha ${ }^{-1}$, T2: Rice husk @5 $\mathrm{t} \mathrm{ha}^{-1}$, T3: Rice straw @ $2.5 \mathrm{t} \mathrm{ha}^{-1}+$ Rice husk @ $2.5 \mathrm{t} \mathrm{ha}^{-1}$, T4: Rice straw @ $1.25 \mathrm{t} \mathrm{ha}^{-1}+$ Rice husk@3.75 t ha ${ }^{-1}$, T5: Rice straw@ $3.75 \mathrm{t} \mathrm{ha}^{-1}$ + Rice husk@1.25 t ha ${ }^{-1}$, T6: Polythene mulch and T7: Control. A uniform dose of $20 \mathrm{~kg} \mathrm{~N} / \mathrm{ha}$ in the form of urea, $40 \mathrm{~kg}$ $\mathrm{P}_{2} \mathrm{O}_{5} /$ ha in the form of single superphosphate and $30 \mathrm{~kg} \mathrm{~K}$ O/ha in the form of muriate of potash were applied in the research plots one day before sowing. Sowing was done on $26^{\text {th }}$ 
June, 2019 by following a uniform spacing of $45 \mathrm{~cm} \times 10 \mathrm{~cm}$.

The biometric observations were recorded on growth characters like plant height and number of branches per plant on five sample plants selected randomly from each net plot. For dry matter studies three plant samples were uprooted from each gross plot. Postharvest studies include number of pods per plant and test weight $(\mathrm{g})$ recorded on the same five plants sample from each net plot at the time of harvest. The seed yield ( $\mathrm{kg} / \mathrm{ha})$, stover yield $(\mathrm{kg} / \mathrm{ha})$, biological yield $(\mathrm{kg} / \mathrm{ha})$ and harvest index $(\%)$ were also recorded from each net plot at the time of harvest. All the data obtained were statistically analysed by the method of analysis of variance to test the significance of the treatment effects as well as result interpretation as given by Gomez and Gomez (1984). F-test at 5\% level of probability was used to test the significance of treatment effect and wherever the "F" test was significant critical difference (CD) values were given at $5 \%$ level of significance.

\section{Results and Discussion}

\section{Effect of mulching on the growth characters of soybean}

Data concerning the plant height, number of branches per plant and dry matter accumulation per plant as influenced by different mulching practices are presented in table 1 . The mean plant height of soybean is significantly influenced by different mulching practices at all observation intervals.

The maximum plant height is observed in polythene mulching (T6) followed by the treatment mulching with Rice straw @ $5 \mathrm{t} \mathrm{ha}^{-1}$ (T1). However, both are at par with each other. This might be due to the better suppression of weed growth and reduced loss of nutrients from the soil as compared to other treatments. The least plant height is observed in control treatment (T7). Significantly maximum number of branches per plant is recorded in polythene mulching (T6) followed by the treatment mulching with Rice straw @ $5 \mathrm{tha}^{-1}$ (T1) and this remained at par with the rest of the treatments except for control which recorded the lowest number of branches per plant.

This may be due to the competitive advantage of the crop over the weeds for better sunlight and nutrients. The mean dry matter accumulation per plant is also effected significantly by different treatments of mulching where polythene mulching (T6) reported highest dry matter accumulation per plant followed by mulching with Rice straw @ $5 \mathrm{t} \mathrm{ha}^{-1}$ (T1). However, both are found to be par with each other. This may be due to the competitive advantage of the crop over the weeds for better sunlight and nutrients resulting in high photosynthetic activity. Control (T7) significantly reported the lowest dry matter accumulation per plant.. These results are supported by the findings of Hidayat et al., (2019), Kader et al., (2017), Eid et al., (2013), Saren et al., (2008), Subrahmaniyan et al., (2008),Kumar and Ngachan (2001).

\section{Effect of mulching on yield and yield attributes of soybean}

Data concerning number of pods per plant, test weight, grain yield, stover yield, biological yield and harvest index as influenced by mulching are reported in table 2 . The number of pods per plant and test weight is significantly influenced by different mulching treatments. Out of all treatments polythene mulching recorded highest number of pods per plant and test weight followed by mulching with rice straw @ $5 \mathrm{t} \mathrm{ha}^{-1}$ (T1). However, both are found to be par with each 
other. Control (T7) significantly reported the lowest number of pods per plant and test weight. This may be due to less weed competition, better utilization of nutrients and moisture at flowering stage, good translocation of photosynthates from source to sink which reduced the abscission of pods and increase in the test weight by mulching. These results are supported by the findings of Kader et al., (2017), Hidayat et al., (2019) and Singh (2005).

Table.1 Growth characters of soybean as influenced by mulching

\begin{tabular}{|l|c|c|c|}
\hline Treatments & $\begin{array}{c}\text { Plant } \\
\text { height(cm) }\end{array}$ & $\begin{array}{c}\text { No. Of } \\
\text { branches per } \\
\text { plant }\end{array}$ & $\begin{array}{c}\text { Dry matter } \\
\text { accumulation } \\
\text { per plant (g) }\end{array}$ \\
\hline T1 & 89.73 & 22.33 & 39.49 \\
\hline T2 & 79.81 & 20.07 & 28.75 \\
\hline T3 & 80.75 & 20.07 & 33.65 \\
\hline T4 & 77.53 & 21.47 & 30.20 \\
\hline T5 & 82.10 & 21.93 & 34.87 \\
\hline T6 & 96.77 & 23.60 & 44.01 \\
\hline T7 & 68.77 & 16.87 & 26.23 \\
\hline General mean & 82.20 & 20.90 & 33.88 \\
\hline S.Ed. $( \pm)$ & 3.78 & 1.21 & 2.59 \\
\hline C.D. $(\mathrm{P}=0.05)$ & 8.23 & 2.63 & 5.64 \\
\hline
\end{tabular}

Table.2 Yield and yield attributing characters of soybean as influenced by mulching

\begin{tabular}{|c|c|c|c|c|c|c|}
\hline Treatments & $\begin{array}{l}\text { No. Of } \\
\text { pods per } \\
\text { plant }\end{array}$ & $\begin{array}{c}\text { Test } \\
\text { weight } \\
\text { (g) }\end{array}$ & $\begin{array}{c}\text { Grain } \\
\text { yield } \\
(\mathbf{k g} / \mathbf{h a})\end{array}$ & $\begin{array}{l}\text { Stover } \\
\text { yield } \\
\text { (kg/ha) }\end{array}$ & $\begin{array}{l}\text { Biological } \\
\text { yield } \\
\text { (kg/ha) }\end{array}$ & $\begin{array}{c}\text { Harvest index } \\
(\%)\end{array}$ \\
\hline $\mathrm{T} 1$ & 78.2 & 11.2 & 2336.0 & 2991.3 & 5324.0 & 43.9 \\
\hline $\mathrm{T} 2$ & 52.6 & 9.3 & 1669.3 & 2456.7 & 4106.0 & 40.7 \\
\hline T3 & 66.3 & 10.1 & 1923.3 & 2643.3 & 4566.7 & 42.1 \\
\hline $\mathrm{T} 4$ & 59.6 & 9.5 & 1794.7 & 2523.7 & 4318.3 & 41.5 \\
\hline T5 & 74.1 & 10.8 & 2192.3 & 2883.7 & 5076.0 & 43.1 \\
\hline T6 & 84.2 & 11.9 & 2554.7 & 3260.7 & 5798.7 & 44.1 \\
\hline T7 & 43.3 & 9.2 & 1165.0 & 1819.3 & 2984.3 & 39.1 \\
\hline General mean & 65.4 & 10.29 & 1947.9 & 2654.0 & 4596.2 & 42.0 \\
\hline S.Ed. $( \pm)$ & 3.29 & 0.70 & 109.40 & 145.19 & 248.06 & 0.68 \\
\hline C.D. $(\mathrm{P}=0.05)$ & 7.18 & 1.53 & 238.37 & 316.34 & 540.48 & 1.49 \\
\hline
\end{tabular}

Grain yield, stover yield, biological yield and harvest index are significantly influenced by different practices of mulching where, polythene mulching (T6) observed highest in all cases followed by mulching with rice straw@ $5 \mathrm{t} \mathrm{ha}^{-1}(\mathrm{~T} 1)$. This may be due to the better suppression of weed growth, efficient utilization of resources, better accumulation of dry matter during the vegetative growth and mobilization of photosynthates from source to sink. Control (T7) significantly reported the lowest in all cases. Among the 
mulching treatments rice husk @ $5 \mathrm{tha}^{-1}$ (T2) recorded the lowest yields because of higher weed competition. These results are supported by the findings of Eid et al., (2013), Sarmah (1986), Kader et al., (2017), Arora et al., (2011), Maan and sing (2009), Kaul and Sekhon (1977), Singh (2005) and Yadav (2005).

\section{References}

Abdelhamid, M.T., Horiuchi, T. and Oba, S. (2004). Composting of rice straw with oilseed rape cake and poultry manure and its effects on faba bean (Vicia faba L.) growth and soil properties. Bioresour. Technol., 93(2): 183-189.

Alexander, M. (1977). Pulse crop, Oxford and IBH publishing co. pvt. Ltd. PP.SS.

Anzalone, A., Cirujeda, A., Aibar, J., Pardo, G. and Zaragoza, C. (2010). Effect of biodegradable mulch materials on weed control in processing tomatoes. Weed Tech., 24(3): 369-377.

Arora, V.K., Singh, C.B., Sidhu, A.S. and Thind, S.S. (2011). Irrigation, tillage and mulching effects on soybean yield and water productivity in relation to soil texture. Agric. Water Manag., 98(4): 563-568.

Eid, A., Bakry, B. and Taha, M. (2013). Effect of pulse drip irrigation and mulching systems on yield, quality traits and irrigation water use efficiency of soybean under sandy soil conditions. Agric. Sci., 4: 249-261.

FAO. (1982). Organic materials and soil productivity. FAO Soil Bulletin. 35 GIN-FAO, Rome.

from electron transport to the canopy (Study case: Glycine max L. Merr).

Gomez, K. A., and Gomez, A. A. (1984). Statistical procedures for agricultural research. John Wiley \& Sons, New York: 8-20.

Hidayat, T., Koesmaryono, Y. and
Ghulamahdi, M. (2019). Intensifying of reflected radiation under oil palm canopy and its effect on growth and production of soybean. In IOP Conference Series: Earth and Environmental Science (Vol. 365, No. 1, p. 012001). IOP Publishing.

IRRI, Los Banos, Laguna, Philippines. pp. 501-519.

June, T. (2002). Environmental Effects on photosynthesis of C3 plants: scaling up

Kader, M.A., Senge, M., Mojid, M.A. and Nakamura, K. (2017). Mulching typeinduced soil moisture and temperature regimes and water use efficiency of soybean under rain-fed condition in central Japan. Inter. Soil and Water Conserv. Res., 5(4): 302-308.

Kaul, J.N. and Sekhon, H.S. (1977). Soyabean yield improved by inoculation and mulching. World Crops and Livest., 29: 248-49.

Khan, M.A.H. (2001). Micro-climatic manipulation and adaptation of quality protein maize (QPM) under dry land conditions by using tillage practices. Final Report. BARC/ARMP funded Contract Res. Project, pp.72.

Kumar, S. and Ngachan, S.V. (2001). Performance of winter groundnut (Arachis hypogaea) with polyethylene mulch under rainfed condition of Manipur valley. Indian J. Agron., 46(1): 151-155.

Liu, Z., Wang, G., Liu, H.Y., Lei, L. and Wu, Y. (2000). The effect of different mulching methods with whole maize straw in dry-land on maize yield. Shanxi Agric. Sci., 28: 20-22.

Maan, C.S. and Mandeep, S. (2009). Beneficial effects of mulching in soybean cultivation. Agric. Update, 4(1/2): 1-2.

Mendoza, T.C. (1989). Nutrient cycling: The key to economical farming practice. In Proceedings of the International 
Training Course on Sustainable Agriculture (ECO- Farming) College, Laguna, Philippines. pp. 67-80.

Mendoza, T.C. and Samson, R.O.G.E.R. (1999). Strategies to avoid crop residue burning in the Philippines context. Resource Efficient Agricultural Production (REAP), Canada. pp. 1-18.

Patnaik, S. (1978). Natural sources of nutrients in rice soils. In: Soils and Rice.

Roldán, A., Caravaca, F., Hernández, M.T., Garcia, C., Sánchez-Brito, C., Velásquez, $\mathrm{M}$. and Tiscareno, $\mathrm{M}$. (2003). No-tillage, crop residue additions, and legume cover cropping effects on soil quality characteristics under maize in Patzcuaro watershed (Mexico). Soil and Tillage Res., 72(1): 65-73.

Sandler, H.A., Brock, P.E. and Heuvel, J.E.V. (2009). Effects of three reflective mulches on yield and fruit composition of coastal New England winegrapes. Am. J. of Enol. and Viticult., 60(3): 332338.

Saren, B.K., Mandal, K. and Bag, N. (2008). Effect of mulching and row spacing on growth, seed yield and oil yield of rainfed Niger (Guizotia abyssinica) in red and lateritic acid belt of West Bengal. Indian J. Agric. Sci., 78(6): 557-559.

Sarmah, S. C. (1986) Effect of mulching on seedling emergence and yield of soybean. Soybean Genet Newslett 13: 74-77.

Singh, A. (2005). Water productivity of bed planted soybean (Glycine max (L.) Merrill.) as influenced by mulching, irrigation regimes and lopping. Doctoral dissertation, Punjab Agricultural University, Ludhiana, India.

Smart, J.R. and Bradford, J.M. (1999). Conservation tillage corn production for a semiarid, subtropical environment. Agron. J., 91(1): 116-121.

Subrahmaniyan, K., Kalaiselvan, P. and Arulmozhi, N. (2008). Weed control in groundnut (Arachis hypogaea L.) with polyethylene film mulching. Int. J. of Pest Manag., 48(3): 261-264.

Yadav, R.D. (2005). Effect of mulching and sulphur on mustard [Brassica juncea (L.) Czernj and Cosson] under varying levels of irrigation. Ph.D. (Ag.) Thesis, Rajasthan Agricultural University, Bikaner.

\section{How to cite this article:}

Daniel Anand, D., M. Sumarjit Singh, Jamkhogin Lhungdim, N. Surbala Devi and Gopimohan Singh, N. 2020. Effect of Mulching on Growth and Yield of Soybean (Glycine max (L.) Merrill). Int.J.Curr.Microbiol.App.Sci. 9(09): 3313-3318. doi: https://doi.org/10.20546/ijcmas.2020.909.412 